\title{
Prospects of Application of International Standards in Financial Reporting by Small and Medium-size Businesses in Georgia
}

\author{
Levan Sabauri ${ }^{1} \&$ Nadezhda Kvatashidze ${ }^{1}$ \\ ${ }^{1}$ Ivane Javakhishvili Tbilisi State University, Georgia \\ Correspondence: Levan Sabauri, Associate Professor, Ivane Javakhishvili Tbilisi State University, Georgia.
}

Received: January 11, 2018

Accepted: January 30, 2018

Online Published: February 8, 2018

doi:10.5430/ijba.v9n2p1

URL: https://doi.org/10.5430/ijba.v9n2p1

\begin{abstract}
Drafting financial statements according to the complete (global) International Financial Reporting Standards (IFRS) in place by small and medium-size businesses (enterprises) is a laborious and costly task, so much so that it does not comply with the cost-utility ratio guideline of the IFRS conceptual framework.

The International Accounting Standards Board (IASB) developed financial reporting standards adequate with the transactions, deals and information users of the small and medium-size businesses, which resulted in simpler IFRS and ultimately cheaper financial statements and more useful information. Most of the businesses in Georgia are small or medium-size, so simplified IFRS allow them not only to supply information without much effort and excessive costs but develop further and attract investments.
\end{abstract}

Keywords: IFRS for small and medium-size businesses, IFRS simplification, balance between the information supply costs and utility thereof, prospects of application of IFRS by small and medium-size businesses in Georgia

\section{Introduction}

Small and medium-size businesses hold 95\%-99\% share at the organized market, so the sector is crucial for the national economy. The said businesses effect a number of foreign trade transactions and are players at the capital market. In terms of their standing and prospects, information about them is important to the other market players, fore and foremost the funders like banks, creditors and potential investors.

The International Accounting Standards Board (IASB) set the goal of developing the financial reporting standards for small and medium-size businesses to allow them supply the information to all the market players relevant to decision-making.

As to the complete (global) International Financial Reporting Standards (IFRS), they are designed for international corporations trading at the stock exchange. The standards contain regulations for registration of the operations and transactions of the listed companies. Not infrequently, those transactions imply complex calculations, detailed interpretations etc., which all in all call for a lot of labor and financial costs (information gathering, processing, verification and spread).

The transactions and deals closed by small and medium-size businesses differ from those of the listed companies and, consequently and the interests of their information users do too. Therefore, incurring costs for drafting financial statements in line with complete IFRS is unjustifiable. Under the IFRS conceptual framework, the information supply costs are to be limited: the information costs incurred for financial statements designed for owners etc. interested persons are not to exceed the utility of the information (Conceptual Framework for Financial Reporting, 2010). The standards for small and medium-size businesses determine the same requirement (InternationalFinancialReporting Standard forSmallandMedium-sized Entities, 2009).

Thus, in developing the IFRS for small and medium-size businesses IASB pursued the following goals:

- $\quad$ simplification of accounting;

- limited financial statement drafting costs;

- $\quad$ business-specific information supply to facilitate the users' decision-making; 
- supply of the information allowing the Management's assessment of the assigned resources in terms of are efficient management thereof.

\section{Strengths and Weaknesses of the IFRS for Small and Medium-size Businesses}

Pursuing the set tasks and purposes, in June 2009, the International Accounting Standards Board adopted the International Financial Reporting Standards for small and medium-size businesses across the world. According to the new Financial Reporting Standards, the small and medium-size businesses are the ones that:

- have no public liability: and

- publish financial statements for general use by outside users.

Users of the information included in the financial statements of the small and medium-size businesses are more interested in the short-term cash flows, liquidity and solvency of a company than its market value (Module 1-Small and Medium-sized Entities, 2009). The number of the outside users of the information included in the financial statements of the small and medium-size businesses is increasing. Those are:

- banks - making loan issuance decisions;

- $\quad$ suppliers - making decisions regarding supply of goods/services;

- credit -rating agencies etc. - rating a company;

- clients - making decisions regarding maintenance of business relationships;

- $\quad$ shareholders - who are not managers.

The IFRS for small and medium-size businesses is an independent standard, which relies on the guidelines of complete (global) IFRS. The new standard was adopted with due regard to the potential, events and transactions specific to small and medium-size businesses. It aims at simpler financial reporting and minimizes application of the complete IFRS.

The special standard made it possible for small and medium-size businesses to compile IFRS-based reports. There is but small difference between the complete IFRS and that of the small and medium-size businesses, so that they can use the global IFRS without much effort. The IFRS for small and medium-size businesses is much simpler and consequently, by applying it the enterprises can save reporting costs. Apart from that, the IFRS for small and medium-size businesses has the advantages below:

Access to Funding. Access to credit resources is simpler for the businesses applying special standard for small and medium-size businesses. Namely, submission of reports made out on the grounds of the IFRS for small and medium-size businesses makes it easier to get foreign credit facilities, including the commodity credits since the sellers can analyze the standing of the buyers.

Also, the IFRS for small and medium-size businesses makes it possible to diversify funding at the expense of own capital, i.e. by attracting multiple investors, including international funds.

Professional Advancement of the Staff. The IASB believes that application of the IFRS specific to the small and medium-size businesses is the first step on the way to the more widespread and updated standards. The IFRS for small and medium-size businesses is instrumental to professional advancement of the employees, especially in the field of finances.

International Audit. Drafting a report in accordance with IFRS makes an enterprise eligible for the international audit, which bolsters its internal control and adds value to its financial report and the firm as such.

Waiver of the National Standards. In some countries, the businesses drafting their financial reports in accordance with the IFRS for small and medium-size businesses may disregard the relevant national standards and by doing so, avoid overloading.

Stable Reporting Regulations. Not infrequently, accountants of major corporations applying complete IFRS face a problem of regular replacement of old standards with the updated ones. Meanwhile, the IFRS for small and medium-size businesses is not subject to frequent amendments. For instance, since its adoption in July 2009, it was only in 2015 that the standard was amended. Developers of the standards are expected to amend the IFRS for small and medium-size businesses once in 3-5 years (Paul Pacter, 2011).

However, the simplified version of IFRS is not completely flawless. First of all, its introduction is quite costly for small and medium-size businesses so much so that it may be comparable to application of complete IFRS. Secondly, a small firm aspiring for becoming a public company and issue its shares, bonds, bills of exchange will have to draft 
financial reports according to the complete IFRS. Thirdly, it's still unclear whether investors trust the "simpler reports" for more findings make the investors' decisions more substantiated.

\section{Changes to the IFRS for Small and Medium-size Businesses}

In 2015, the IASB recommended changes to the IFRS for small and medium-size businesses, which simplified a number of issues mandatory for financial statements (2015 Amendments to the IFRS for SMEs, 2015). Namely, several issues irrelevant to private business were exempted; recognition and assessment of the financial report items is now simpler; the alternative accounting techniques are limited; there are fewer information disclosure requirements and explicatory notes. All in all, the new, simpler standard has cut the financial reporting costs.

Comparison to complete IFRS reveals three groups of simplifications: first, some of the topics discussed in the global IFRS, such as computation of the equity income, segmental and interim financial statement, accounting of the long-term assets for sale and termination of business are not to be found in the IFRS for small and medium-size businesses as irrelevant. Second, the standard contains much fewer alternative accounting techniques and the small and medium-size businesses are expected to apply only a simpler technique contained in the complete IFRS. Third, the new standard requires limited explications in the financial report. As a result, the IFRS for small and medium-size businesses makes up merely $10 \%$ of the complete IFRS. The same holds true for requirements of the complete IFRS concerning the explicatory notes (International Financial Reporting Standards (IFRS) for small and medium enterprises, 2012).

\subsection{The Most Urgent and Important Changes}

Submission of the financial report: along with the International Accounting Standard (IAS 1: "Presentation of Financial Statements"), the IFRS for small and medium-size businesses requires that in the financial statement there is at least one period for the comparable information. Meanwhile, under complete IFRS, the financial statement containing the financial standing, profit-loss, total income, cash flow reports and the one concerning changes in own capital is to reflect information regarding two reporting dates. Besides, instead of the total income report and two reports on undistributed profit, the small and medium-size businesses can now present a consolidated report on total income and undistributed profit. However, it is only possible when changes in the capital during the reporting period resulted from only profit or loss, dividend payment, adjustments made in the passed periods and changes in the accounting policy.

Combined financial statement: another innovation in the IFRS for small and medium-size businesses is the concept of the combined financial statement, which is a combination of the statements drafted by legally unrelated enterprises (the so-called informal holding) owned by a single entity (PWC, 2013). The combined financial statement is a single financial report drafted by two or more businesses controlled by the same investor. Under the IFRS for small and medium-size businesses, drafting the combined financial statement, which relies on the guidelines of consolidation, is not mandatory. Enterprises may draft the statement as required, for instance, for initial appraisal of their consolidated report prior to merger or assessment of efficiency of the holding group and, also, forecasting. It should be said that the combined financial statement is not the consolidated report of the group as it is described in IAS 27: "Consolidated and Separate Financial Statements" and, therefore, it does not meet the requirements of the Stock Exchange.

Consequently, although the structure of the small and medium-size businesses differs from that of a holding, the IFRS designed for them came up as a major incentive for their development. They are now free to decide, which enterprises could be consolidated under a single investor control. It is up to the auditor's professional judgment to define whether the consolidation perimeter is wrong and in case of high risk, take preventive measures (SergeyModerov, 2009). The combined report of a business group is to disclosure all the business-related risks and benefits and not only those that the Management would like to reveal.

Fixed assets: they are accounted by the prime cost and depreciation model. As to the revaluation model, it may be applied only by means of the capital. Depreciation to the component is charged only when the main part of the asset assigned to fixed assets differs in terms of "Different Models of Utilization of the Economic Benefit" Bdo. Ifrs for Smes at a Glance (2015). The term, residual value and depreciation rate of the fixed assets are to be revised in case of major changes to the asset or its utilization (and not annually).

Investment assets: by application of the prime cost model, the investment assets are accounted as fixed assets, if reliable assessment of the actual value of the assets is impossible.

The loan consumption costs are acknowledged as costs and are never capitalized. 
State grant: if all the grant conditions are met, a state grant is acknowledged as income. If the grant is given prior to fulfillment of its conditions, it is acknowledged as a liability. As against the complete IFRS according to which the asset-related grants in the statements are specified as income or by way of reduction of the value of the acquired /self-produced assets, the IFRS for small and medium-size businesses prescribes uniform itemization of the state grants. The small and medium-size businesses are to record grants as income and acknowledge the State-provided asset at its real value.

Intangible assets: the intangible assets are accounted by the prime cost model. The reevaluation model cannot be applied. The development work costs are to be acknowledged as the period cost and cannot be capitalized. The intangible assets have a definite useful life and when its reliable determination is impossible, the useful life expectancy shall not be over 10 years.

Consolidation of enterprises and Goodwill (Ernst \& Yang, 2010): the purchase method is applied; all the costs directly incurred for the sake of consolidation of enterprises are capitalized and cannot be acknowledged as costs. The Goodwill is amortized but if an enterprise is unable to accurately determine the useful life of its Goodwill, it shall be defined as 10 years.

Special activities: if the real value cannot be determined without extra costs and efforts, in agriculture they apply the historical cost model. In oil and gas production and mining the prospecting costs may not be itemized as expenditure.

Financial instruments: regarding the financial instruments - the most complex part of the international standards, the IFRS for small and medium-size businesses suggests that we rely either on section 11: "Basic Financial Instruments" or section 12: "Additional Financial Instruments Issues" or complete IFRS 39: "Financial Instruments: Recognition and Assessment". If a company relies on section 11 and 12, it should take into account that in accordance with the IFRS for small and medium-size businesses, virtually all the financial instruments are to be accounted at their amortized cost. Consequently, accounting complex financial instruments at their actual cost as it is frequently the case in complete IFRS in the IFRS for small and medium-size businesses is unacceptable.

The basic financial instruments available to all the small and medium-size businesses - bills payable, bills receivable, loans, deposits, bonds etc. credit instruments, inconvertible preferred shares - are accounted at amortized cost. All the other instruments accounted at their actual value by way of recognition of profit and loss (PWC, 2009). The IFRS for small and medium-size businesses prescribe simpler recognition termination terms and hedging accounting requirements.

Fixed charge pension scheme: the unguaranteed service fee of the previous periods is immediately recognized in the profit-loss sheet and the costs cannot be amortized within the period. For the sake of assessment of its liabilities and costs, an enterprise is to apply the projected unit credit method unless it requires inexpedient costs and effort. All the actual profit or loss is to be recognized in the period they arise in, either in the profit-loss statement etc. total incomes.

Investment in the associated companies and joint activities: investments in the associated companies and joint activities are to be accounted by application of one of the methods below: the prime cost model; the venture capital method or the real value model. When the associated and joint venture stocks are listed, an investment is to be recognized by the real value model solely. The investment in the associated companies, with the stock quotas published is to be accounted at the real value and the changes assigned to the profit or loss.

Sale of a foreign affiliate: in the consolidated statement, the exchange rate difference is itemized in another total income as a capital component. According to complete IFRS, in the sale of a foreign affiliate, the relevant capital item is to be assigned to the current period profit-loss statement. Meanwhile, in line with the IFRS for small and medium-size businesses, a company is to transfer the exchange rate difference directly to undistributed profit.

The omissions: presentation of the equity income index; presentation of the interim financial statement; presentation of the segmental financial statement; regulations for accounting the assets for sale.

The uniformly prepared financial statement of a small or medium-size business provides clear, transparent and comparable information and allows the interested persons to get a clear notion of its standing, increases its loan and investment prospects, as well as the international trade potential.

\section{The IFRS for Small and Medium-size Businesses in Georgia: Prospects}

The USAID supported "Accounting Reform in Georgia" project was implemented in 1998-2000. It aimed at introduction of the complete financial International Financial reporting Standards at the joint stock companies in Georgia. To this end, the balance sheet items were reclassified, profit and capital taxes adjusted, new code of 
accounts and new approaches to recognition of the financial statement items introduced etc. Also, the project had an educational aspect: the standards were translated, professionals retrained, trainers trained etc. All the works were successfully performed, so the Georgian companies started application of complete IFRS.

As said above, according to IFRS for small and medium-size businesses, a small or a medium-size company is not public, which means that their stocks, bonds and bills of exchange are not listed on the stock exchanges. Although the said enterprises have no public importance but they publish general purpose financial statements for outside users. It should be said that a company regarded as small or a medium-size may actually be of any size. Therefore, the main criterion of applying the "simplified" standard is that a company is not public.

Meanwhile, a company is public if its credit or equity instruments are already negotiable or to start negotiating at the market (national or foreign stock exchanges, over-the-counter markets). Also, the public companies, such as banks, credit unions, insurance companies, brokerages (dealer firms), interest foundations are the ones focused on the trust-based management of assets of multiple entities.

However, the definition of the standard aims at informing legislative and regulatory bodies, standard determining organizations, companies and their auditors about scope of application thereof and which enterprises cannot apply the IFRS for small and medium-size businesses. Relying on the standard, a country that decides to apply the "simplified" standard may determine quantitative aspects of small and medium-size businesses. Therefore, the Law of Georgia "On Accounting, Reporting and Audit" defines four types of enterprises and the relevant criteria.

Table 1. Enterprise types, the definition criteria, reporting and audit requirements

\begin{tabular}{lllllll}
\hline Enterprise Type & Assets (GEL) & Turnover (GEL) & Employees & $\begin{array}{l}\text { Statement } \\
\text { preparation }\end{array}$ & Publication & $\begin{array}{l}\text { Mandatory } \\
\text { audit }\end{array}$ \\
\hline $\begin{array}{l}\text { Category 4 (the } \\
\text { so-called micro*) }\end{array}$ & $<1000000$ & $<2000000$ & $<10$ & Simplified & No & No \\
$\begin{array}{l}\text { Category 3 (the } \\
\text { so-called small*) }\end{array}$ & $<10000000$ & $<20000000$ & $<50$ & IFRS for SME & Brief & No \\
$\begin{array}{l}\text { Category 2 (the } \\
\text { so-called medium) }\end{array}$ & $<50000000$ & $<100000000$ & $<250$ & IFRS for SME & Complete & Yes \\
$\begin{array}{l}\text { Category 1 (the } \\
\text { so-called large) }\end{array}$ & $>50000000$ & $>100000000$ & $>250$ & IFRS & Complete & Yes \\
\hline
\end{tabular}

Since 2000, financial statements have to be prepared according to IFRS.

* Reporting requirements for categories 3-4 have been simplified (under the legislation, IFRS for SME was required)

** Audit requirement compulsory for 1-2 category enterprises is going to be met by the majority of those subject to the effective audit requirements and business parameters.

Under the abovementioned legislation, accounting and reporting are performed according to IFRS for SME. In 2016, the IFRS for SME was translated and published in Georgia.

Most of the companies in Georgia operate at the internal market since their securities are not listed. They do not issue bonds and equity instruments and, generally, do not invest in the affiliate or associated companies. Therefore, they do not have to develop consolidated, interim or segmental financial statements, calculate the equity income, prepare detailed explicatory notes and perform etc. complex and laborious accounting-related tasks. Consequently, small businesses are now applying simplified accounting: they choose the most relevant alternatives of the complete IFRS and even disregard the issues like the deferred profit tax. The fact is that most of the Georgian enterprises apply "mixed" accounting, with some of the balance items reported according to complete IFRS (e.g. fixed assets, inventory holdings) and the others in line with the Tax Legislation (e.g. profit tax, bad debts, interest costs). We believe that accounting problems calling for unreasonable costs and efforts on part of the small and medium-size businesses is the main reason behind the situation.

The latest National Statistics Service report says that by 1 July 2016, in quantitative terms, the economic units registered in Georgia were as follows: 


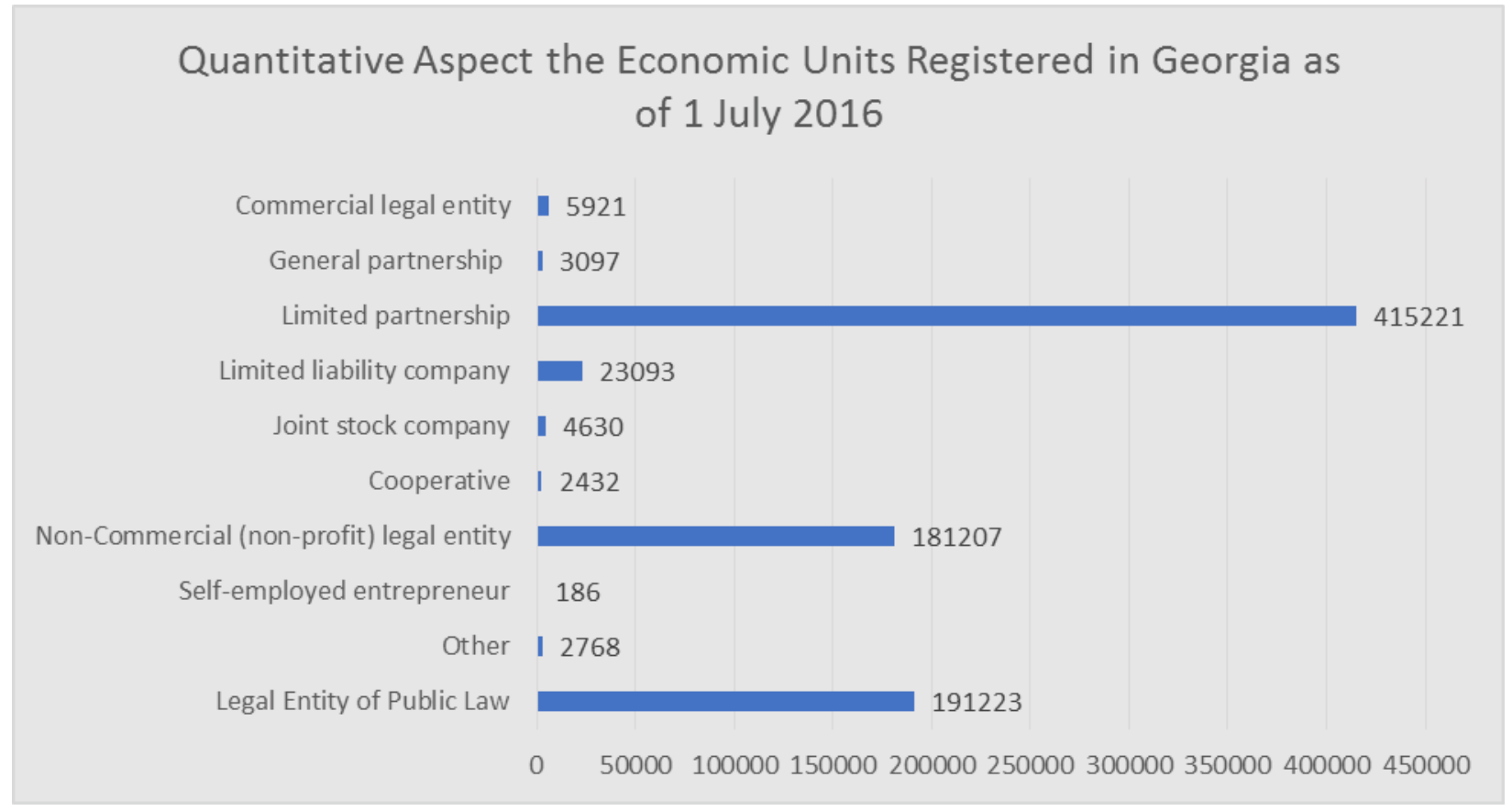

Figure 1

It should be said that in terms of their size, the National Statistics Service groups the enterprises according to its own macroeconomic indexes that rely on the following standards: an enterprise with its revenue below 500000 GEL falls into the group of small enterprises; accordingly, the one whose revenue is 500 000-1500 000 GEL is a medium-size company, while a company of over 1500000 GEL revenue is regarded large. Relying on the aforementioned data, the figure below shows the total production in Georgia in terms of size of the companies:

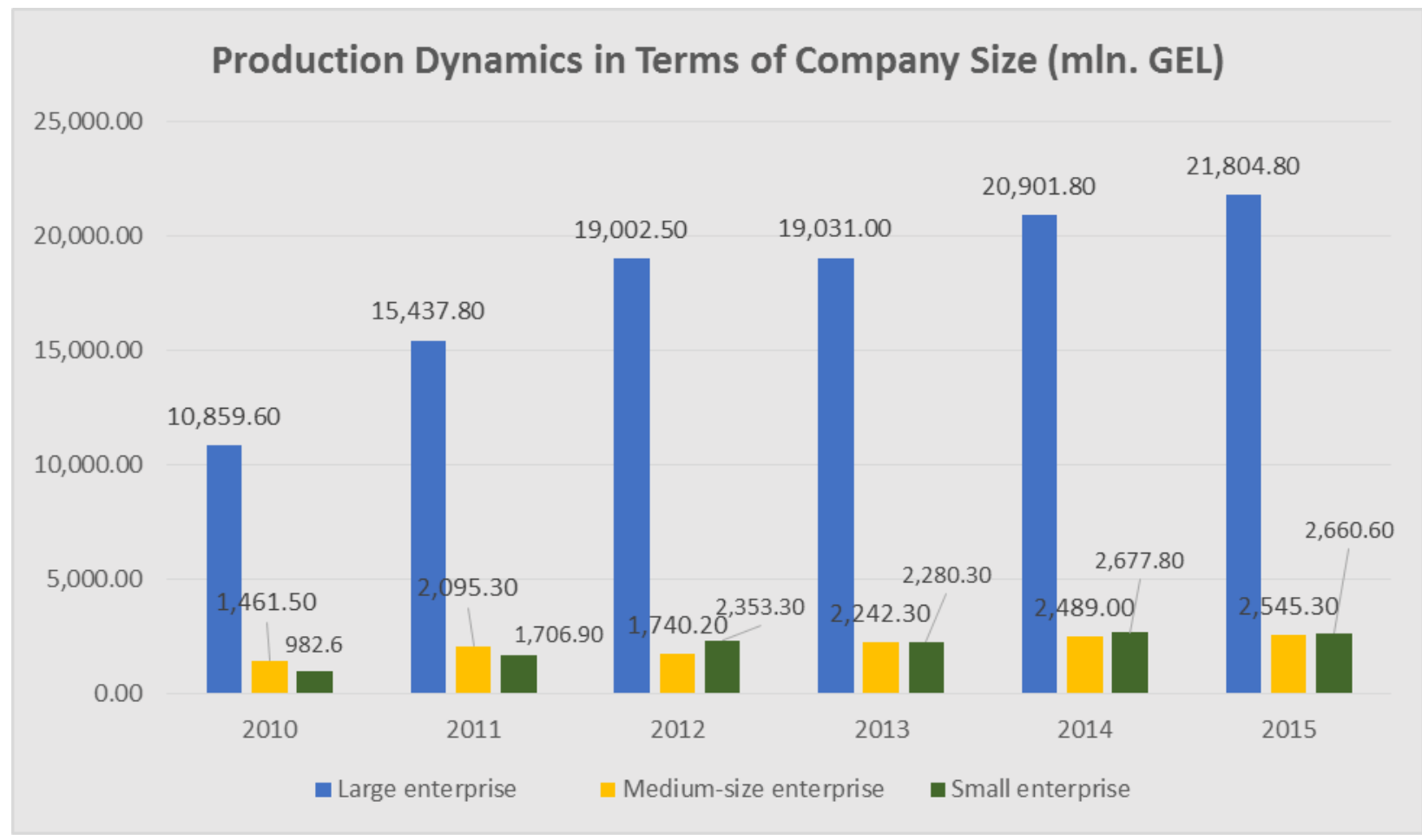

Figure 2 
According to the statistical standards, in terms of the turnover, $82 \%$ of the enterprises are large. However, subject to the new criteria, $99 \%$ of the medium-size enterprises are going to fall into the categories of small and micro-enterprises, while $95 \%$ of the large ones will be deemed medium-size.

According to the standards prescribed by the Law of Georgia "On Accounting, Reporting and Audit", the number of the companies by categories has not been determined as yet. Although $90-95 \%$ of the enterprises incorporated in Georgia are expected to fall into the category of micro- and small enterprises.

Table 2. Turnover according to the legal form and number of the companies

\begin{tabular}{|c|c|c|c|c|c|c|c|c|c|c|c|c|c|}
\hline \multirow{3}{*}{ Year } & \multirow{3}{*}{$\begin{array}{c}\text { Total of } \\
\text { mln. } \\
\text { GEL }\end{array}$} & \multicolumn{12}{|c|}{ Including } \\
\hline & & \multicolumn{2}{|c|}{$\begin{array}{c}\text { Limited liability } \\
\text { company }\end{array}$} & \multicolumn{2}{|c|}{$\begin{array}{l}\text { Joint stock } \\
\text { company }\end{array}$} & \multicolumn{2}{|c|}{$\begin{array}{l}\text { General } \\
\text { partnership }\end{array}$} & \multicolumn{2}{|c|}{$\begin{array}{c}\text { Limited } \\
\text { partnership }\end{array}$} & \multicolumn{2}{|c|}{ Cooperative } & \multicolumn{2}{|c|}{$\begin{array}{c}\text { Self-employed } \\
\text { entrepreneur }\end{array}$} \\
\hline & & $\begin{array}{l}\text { Mln. } \\
\text { GEL }\end{array}$ & $\begin{array}{c}\text { Number } \\
\text { (unit) }\end{array}$ & $\begin{array}{l}\text { Mln. } \\
\text { GEL }\end{array}$ & $\begin{array}{c}\text { Number } \\
\text { (unit) }\end{array}$ & $\begin{array}{l}\text { Mln. } \\
\text { GEL }\end{array}$ & $\begin{array}{c}\text { Number } \\
\text { (unit) }\end{array}$ & $\begin{array}{l}\text { Mln. } \\
\text { GEL }\end{array}$ & $\begin{array}{l}\text { Numbe } \\
\mathrm{r} \text { (unit) }\end{array}$ & $\begin{array}{l}\text { Mln. } \\
\text { GEL }\end{array}$ & $\begin{array}{l}\text { Numbe } \\
\mathrm{r} \text { (unit) }\end{array}$ & $\begin{array}{l}\text { Mln. } \\
\text { GEL }\end{array}$ & $\begin{array}{c}\text { Number } \\
\text { (unit) }\end{array}$ \\
\hline 2010 & $24,400.7$ & $20,325.6$ & 89,986 & $3,005.0$ & 2,218 & 29.4 & 2,714 & 6.8 & 181 & 0.8 & 2,601 & 666.2 & 315,997 \\
\hline 2011 & $36,726.2$ & $29,961.1$ & 103,712 & $3,248.0$ & 2,243 & 29.1 & 2,715 & 7.6 & 181 & 1.2 & 2,609 & $2,270.4$ & 335,301 \\
\hline 2012 & $42,048.0$ & $33,798.7$ & 118,237 & $4,092.4$ & 2,227 & 34.0 & 2,715 & 10.3 & 180 & 0.7 & 2,615 & $2,368.8$ & 344,878 \\
\hline 2013 & $44,327.9$ & $35,994.0$ & 135,694 & $4,155.3$ & 2,264 & 33.5 & 2,720 & 9.2 & 181 & 2.4 & 2,649 & $2,693.7$ & 369,188 \\
\hline 2014 & $50,064.7$ & $40,758.3$ & 152,840 & $4,660.4$ & 2,312 & 38.4 & 2,722 & 15.1 & 181 & 0.5 & 3,132 & $2,935.7$ & 395,217 \\
\hline 2015 & $52,858.7$ & $43,430.9$ & 181,207 & $5,118.8$ & 2,432 & 23.9 & 2,768 & 10.7 & 186 & 1.5 & 4,630 & $2,539.3$ & 415,221 \\
\hline
\end{tabular}

Adoption of the IFRS for SME, especially due to the 2015 amendments is going to rouse plenty of Georgian manufacturers' interests since it simplifies accounting and makes it possible to supply the users with financial statements made out in accordance with the IFRS. Therefore, more reliable statements will increase the number of the information users.

Understandingly, introduction the IFRS for SME is going to involve certain difficulties since replacement of the "mixed" accounting may not always be smooth. In this connection, willingness of the Management matters a lot,

\section{Conclusion}

1). The IFRS for SME is a relatively simple and stable standard internationally acknowledged by the users of the financial statements;

2). Relative facility and stability of the IFRS for SME will secure its application in Georgia and make financial statements more accurate;

3). The quality financial statement - useful, reliable and comparable information boosts the number of its users and as evidenced by the International Accounting Standards Board (IASB) surveys will eventually be beneficial to the enterprises. What is implied is a better quality and more comparable financial statement, accessibility to the capital market, higher potential of financial resources, reduced capital costs and international prospects of companies;

4). The Georgian enterprises are going to welcome introduction of the IFRS for SME since its application requires less efforts and smaller costs and makes the financial statement more comparable and eventually, a better quality;

5). Although the securities of most of the small and medium-size businesses in Georgia are not listed, they do not issue bonds and equity instruments or invest in the affiliates or associated companies, the new standard is going to come up as an incentive to investments not only in large businesses but the small and medium-size ones, too. The financial statement made out in accordance with the IFRS for SME will provide useful information to potential investors;

6). In Georgia, introduction of the IFRS for SME may create some problems since in reporting most of the businesses rely on a "mixed" model of complete IFRS and Tax legislation.

\section{References}

2015 Amendments to the IFRS for SMEs. (2015, May). Retrieved from http://www.ifrs.org/IFRS-for-SMEs/Documents/IFRS20SMEs 
Bdo-Ifrs for Smes at a Glance. (2015). A sat, 25. Retrieved 1 January 2015, from http://www.bdointernational.com/Services

Conceptual Framework for Financial Reporting. (2010, September). International Accounting Standards Board, 35-39. Retrieved from http://www.ifrs.org/News/

Ernst, \&Yang. (2010, April). IFRS for small and medium-sized entities. A comparison with IFRS-the basics, 28-33. Retrieved http://www.ey.com/Publication/vwLUAssets/IFRS_for_SMEs_Comparison/\$FILE/IFRS_for_SMEs_

International Financial Reporting Standards (IFRS) for small and medium enterprises. (2012). Why to use this standard in Georgia report on Standards and Codes (ROSC) on the implementation of accounting and audit of the accounts of Tbilisi, Georgia. IFRS Foundation, 20. 30 Cannon Street, London EC4M 6XH, UK. Retrieved 24 September 2015, from http://www.ifrs.org

International Financial Reporting Standard for Small and Medium-sized Entities (IFRS forSMEs). (2009). Retrieved 13 February 2009, from http://go.iasb.org/IFRSforSMEs

Module 1-Small and Medium-sized Entities. (2009). IFRS Foundation: Training Material for the IFRS for SMEs, 9. Retrieved from http://www.ifrs.org/IFRS-for-SMEs/Documents

Paul Pacter. (2011). IFRS for SMEs. IASB Board Member, 4-12. Retrieved 28 November 2011, from https://doi.org/10.4324/9780203103203.ch21

PWC. (2009). IFRS for small and medium-sized entities. Pocket guide 2009, 16. Retrieved from https://www.pwc.com/gx/en/ifrs-reporting/pdf/ifrssme09.pdf

PWC. (2013). Practical guide to IFRS. Combined and carve out financial statements, 1-2. Retrieved from https://www.pwc.com/ng/en/assets/pdf/combined-and-carved-out-financial-statements.pdf

Sergey Moderov. (2009). Thenew IFRS standard for small and medium-sized enterprises (IFRS for SME), 2. Retrieved from http://ifrs-audit.ru/?p=182 